\title{
GEORGE BERNARD SHAW *
}

\begin{abstract}
Alan Tomlinson * *
E que significa este "Deixemo-lo na pobreza?" Significa deixá-lo ser fraco. Deixá-lo ser ignorante. Deixá-lo tornar-se um foco de doença. Deixá-lo exibir sua fealdade e sujeira. Deixá-lo ter filhos raquíticos. Deixá-lo desvalorizar-se e arrastar seus companheiros nesta desvalorização ao vender-se e fazer o trabalho deles. Deixar que suas habitaçōes transformem nossas cidades em amontoados de sórdidos cortiços. Significa deixar que suas filhas infectem nossos jovens com as doenças das ruas e que seus filhos os vinguem transformando a virilidade da nação em escrófula, numa humanidade covarde, cruel, hipócrita, politicamente imbecil, e em todos os outros frutos da opressāo e da sub-nutrição. Significa deixar os indignos tornarem-se ainda menos dignos e os dignos acumularem para eles próprios, não os tesouros nos céus, mas os horrores do inferno sobre a tcrra. Sendo assim é realmente sensato deixá-los na pobreza? 1.
\end{abstract}

Há várias razões para que Bernard Shaw mereça um lugar proeminente em qualquer avaliação da Literatura Britânica durante o século passado e começo do século XX, e uma delas é, me parece, evidente nesta profética acusaçāo citada do prefácio de "Major Barbara". Numa época de mudança social radical e até mesmo revolucionária. Shaw foi um escritor que percebeu a necessidade premente dessa mudança. e tentou através de seu trabalho tornar essa necessidade evidente aos olhos dos outros.

Comentando em outra passagem do prefácio uma determinada cena em "Major Barbara" Shaw escreve:

Há milhōes de Bill Waklers em todas as classes sociais da época atual, e o ponto que cu, como professor de psicologia natural, desejo demonstrar, é que Bill, sem nenhuma mudança em seu caráter ou circunstâncias, qualquer que elas sejam, reagirá de uma deter-

- Conferéncia aos estudantes do Curso de Veräo da Universidade de Oxford. Inglaterra, em 1975, traduzida pela Professora Suzana Pinhelro Machado, Assistente de Lingua e Literatura Inglesa do Departamento de Letras Estrangeiras Modernas da Universidade Federal do Paraná.

* Alan Tomlinson é Mestre em Filosofia pela University of London, Bing's College (1969) com a tese Visual and verbal design in the flays of W. B. Yeats.

Publicou W. B. Yats \& Gordon Craig em Ariel (v. 3, n. 3, julho, 1972). Atualmente, leciona Literatura Inglesa na Huddrsfield Polytechnic.

1 SHAW, George Bernard. Major Barbara. Harmondsworth, Penguin, 1974. p. 17. 
minada maneira e um determinado tratamento, e de outra maneira a outra forma de tratamento 2 .

Creio que Shaw não espera que o tomemos a sério quando afirma ser professor de psicologia natural, afirmaçāo essa tāo inesperada como quando alega no prefácio de "The Millionairess" ser ele um dramaturgo da cminência de Shakespeare. Certamente é uma pilhéria - mas o ponto básico é, sem dúvida, válido e importante. (Se a alegaçāo é brincadeira. se ele não espera que o levemos a sério, talvez Shaw queira chamar a nossa atenção para algo importante que deseja comunicar - as cenas mais engraçadas de suas peças geralmente tem essa finalidade).

A peça é uma demonstraçāo, uma revelação de uma "verdade" premente.

"Esta minha peça. "Major Barbara", é, espero, tāo verdadeira quanto irıspirada"; 3 e, evidentementc, instrutiva, embora Shaw não acrescente a palavra. O que ele acrescenta realmente - ainda que as palavras estejam somente no final de seu prefácio, deveria ser examinado com atençāo, pois nos ajudaria a desfazer a impressão que, receio, possa ter surgido nos que me ouvem, uma impressão que se tornou lugar comum na crítica, pelo menos na crítica de alguns anos atrás, desde que já nāo se ouve mais tanto ultimamente, - de que Shaw não foi um artista, mas sim um propagandista. fstreita e limitadamente didático, e scus propósitos em relação à sua audiência demasiadamente palpáveis, e que essas alegações sejam afinal verdadeiras.

Ele escreve:

Esta minha peça. "Major Barbara", é, espero tāo verdadeira quanto inspirada; mas quem quer que afirme que tudo isto realmente aconteceu e que tudo isso só é crivel e compreensível porque é uma ocorrềncia real, é falando de acordo com as Escrituras, um tolo e um mentiroso, e será denunciado. solenemente amaldiçoado como tal, por mim. o autor, para toda a posteridade. 3

O método didático de Shaw não é o do realismo documentário forense; cle não oferece um fragmento de vida:

Assim Bodger paga seu dinheiro consciência e recebe a absolvição que é negada a Bill. Na vida real, Bill talvez nunca soubesse disso, mas eu, o dramaturgo, cuja funçāo é mostrar a conexão entre coisas que parecem separadas e nāo relacionadas na ordem casual dos eventos na vida real, sou constrangido a revelá-lo a Bill, embora o resultado seja o do Exercito de Salvação perder o seu controle sobre ele definitivamente. 4

Shaw está disposto a exagerar, recombinar, mesmo distorcer, com o fim de esclarecer e dar ênfase. Ele lutou pela causa de Ibsen na Inglaterra, embora seja outro grande revolucionário do teatro de século XIX. Wagner, que,

2 SHAW, Major ..., p. 34.

3 Ibid, p. 49.

4 Ibid., p. 37. 
na realidade, está mais próximo à sua arte, apesar de todas as aparentes divergências entre ambos - como Wagner, e como seus outros principais fdolos culturais - o poeta Shelley e John Bunyan, cujo "The Pilgrim's Progress" ele valorizava mais do que o drama jacobeano-Shaw era antes um alegorista que um realista, e foi em seu ensaio critico "The Perfect Wagnerite" que Shaw explicou como entendia aquele termo:

Se você está agora convencido de que o Ouro do Reno é uma alegoria, então não esqueça que uma alegoria nunca é completamente consistente, a năo ser quando é escrita por alguem sem faculdade dramática, e nesse caso ela é ilegível. Há somente uma maneira de dramatizar uma idéia que é a de se colocar no palco um ser humano possuido por essa idéia, mas nada menos do que um ser humano, com todos os impulsos humanos que o tornam próximo de nós, e por isso, interessante para nós. 5

O próprio Shaw estava longe de ser um autor "sem faculdade dramática", suas peças "dramatizam" ideais, no mais completo sentido possível embora, na verdade, muitas vezes as posiçōes que nelas são apresentadas, deixem de ser claras e francas e, ao contrário, sejam posições de conflito, de dialética: a espécie de situação que levou Shaw, certa vez, a afirmar que as personagens em suas peças sảo. em seus diferentes aspectos, perfeitas.

Realmente, da mesma forma como eu acredito nos críticos que revelam seus preconceitos abertamente, eu diria que considero Shaw não somente como o maior dramaturgo de lingua inglesa, em nosso tempo, mas, também, - mais perfeito desde a Renascença. $O$ ponto pelo qual começo a tratar. refere-se à centralidade das questũes levantadas em suas peças, em relaçāo aos problemas sociais políticos, culturais, e mesmo morais, da época, e que constitue um dos maiores fatores de sua grandeza, e eu voltarei a ele oportunamente. Mais importante para se discutir em primeiro lugar é a natureza de arte através da qual aquelas questōes são levantadas, isto é, a viabilidade cênica do estilo dramático de Shaw. E um fator que merece tomar nosso tempo, pois voces ouvirão ainda muita crítica que afirma que nas peças de Shaw, mesmo nas melhores, só há palavras e não ação, e que as personagens são espíritos e bocas desencarnados. W. B. Yeats notou que qualquer drama que năo use as energias corporais de seus atores ao máximo. é năo dramático, e por conseguinte, sem valor, e Yeats, na realidade, tinha Shaw em mente quando fez essa censura. Considerem, porém. este pequeno exemplo de "Major Barbara". No terceiro ato da peça as personagens centrais reunem-se na fábrica de armamentos de Andrew Undershaft em Perivale St. Andrew. Num lado está um canhāo, no outro uma barraca que é parte da cficina.

Vários bonecos de palha vestidos de soldados, mais ou menos mutilados, com a palha saindo pelos rasgōes, foram jogados para

5 SEAW, George Bernard. The Perfect Wagnerite. In: —_. Major Critical essays. London, Constable, 1955. p. 188. 
TOMLINSON, A. George Bernard Shaw

fora da passagem embaixo do patamar. Outros estão quase em pé encostados no barracāo e outro caiu para a frente e jaz como um cadáver grotesco na plataforma. Mais adiante, à direita, está a porta de um escritório que, como o barracão, é de construção a mais simples possivel. 6

A audiência já tinha sido preparada para compreender aqueles bonecos desde 0 ato I, no qual Undershaft disse estas palavras:

Aqui estou eu. um aproveitador de mutilação e assassinato. Encontro-me com um bom humor todo especial neste momento, porque esta manhã, lá na fundição, nós reduzimos a pedaços vinte $e$ seis bonecos com um canhäo que antes destruia apenas treze.?

Mas no ato III a brincadeira irá se tornar um pouco mórbida:

Undershaft vem do escritório com um telegrama na mão. UNDERSHAFT. Muito bem. Você já viu tudo? Lamento ter sido chamado - (indicando o telegrama). Boas noticias da Mandchuria.

STEPHEN - Outra vitória japonesa?

UNDERSHAFT - Oh! eu não sei. Que lado vencer não nos interessa agora. Nāo. A boa notícia é que a batalha aérea foi um tremendo sucesso. No primeiro ataque foi varrido um forte com trezentos soldados.

CUSINS - (da plataforma) - soldados bonecos?

UNDERSHAFT - (dirigindo-se em direção a Stephen e tirando o soldado caido com um brutal pontapé). Não. Soldados de verdade. 8

A mutilaçāo e o assassinato eram antes uma indulgência verbal; agora sāo uma ação definida e colocada com precisāo que converte aquelas palavras, embora passageiramente, em uma realidade física. E age assim para vários fins: julgando somente pelas palavras que ele profere, Undershaft pode quase parecer como o herói da peça - como tinha sido em certo momento a intenção de Shaw, pois seu primeiro título foi Andrew Undershaft's Profession - e suas "profissões", suas afirmaçōes parecem ser confirmadas pela ação da peça. Mas os gestos e os atos daí decorrentes, na sua realizaçāo, modificam nossas reações à Undershafat e preparam o caminho para a substituição de suas crenças pelas crenças da própria Barbara no climax apocaliptico da peça. Também a moralidade complacente de Stephen, o filho de Undershaft, é violentamente posta em questão. Durante toda a peça Stephen regeita tudo aquilo que seu pai representa, e isto a partir do ponto de vista da moral corrente, da respeitabilidade da classe média. da Igreja Anglicana. E dessa posição que Stephan vê "outra vitória japonesa" como boas noticias, preferindo ignorar a "mutilação e o assassinato" que são parte da amoralidade de seu pai. Algumas dessas implicações estāo, naturalmente, no próprio

6 SHAW, Major ..., p. 129.

7 Tbid., p. 70 .

8 Ibid., p. 130. 
diálogo, mas muitas delas estāo na combinação desse diálogo com a ação, c com a montagem do cenário requeridas pela ação. E porque Shaw usa a ação e o cenário com fim determinado é que ele é tão minucioso e preciso sobre ambos em suas instruçōes cênicas, mesmo que não deseje apontar nada de muito específico através delas. Como neste exemplo tomado ao acaso:

Ela adianta-se e senta-se no sofá. Cusins também move sua cadeira para a frente à sua esquerda. Barbara e Stephen retomam seus lugares. Lomax dá sua cadeira a Sarch e vai buscar outra.,

O elemento visual do esquema de suas peças é muito importante para Shaw; cada detalhe é tão importante como o elemento verbal, a ponto de querer ter o controle dele em suas mãos e todo momento.

Quão completo e expressivo esse controle é quando o talento de Shaw está em todo o seu vigor, desejo agora mostrar através de uma passagem de "Heartbreak House", talvez a maior das peças de Shaw e certamente, a mais completa e sutilmente organizada. $O$ incidente de "Major Barbara" que acabamos de examinar é um gesto especifico, simples e divisível. Heartbreak House oferece estruturas mais complexas, trabalhadas numa escala maior. Ellie Dunn é uma jovem que está prestes a se casar por razōes puramente mundanas com Boss Mangan, um maçante capitalista de meia idade. No ato II da peça Ellie acaba de deixar Mangan em estado hipnótico e entāo, com Mangan adormecido numa cadeira na mesma sala. ela começa a discutir com sua nova amiga, uma mulher mais idosa que ela, Hesione Hushabye. Hesione tenta ser compreensiva mas a infeliz Ellie precisa "toda a força que puder conseguir para me apoiar: algo duro como ferro, pedra, não me importa quão cruel ela seja":

MRS. HUSHABYE (dando de ombros). Muito bem. (Ela senta-se no sofá, em seu lugar anterior). Você se opõe à sirena - bem eu desisto da sirena.

Voce deseja descançar seu peito ferido contra uma pedra de moinho. Bem (cruzando os braços) aqui esta a pedra.

ELLIE (sentando-se a seu lado, mais calma) e bem melhor assim. Voce realmente tem o dom de se adaptar ao humor de cada pessoa. 10

Nada de extraordinariamente complicado até agora. mas a seqüência dos gestos de Hecione cuidadosamente cronometrada, e a chegada das duas nulheres ao sofá mostra o reatamento do entendimento entre elas depois de cuase se desentenderem. Mas ao falar sobre o casamento de Ellie com Mangan elas começam a discordar novamente, e seu desentendimento chega ao auge da seguinte maneira:

9 SHAW, Major ..., g. 67.

10 SHAW, George Bernard Heartbreak house. London, Longmans, 1961. p. 95. 
TOMLINSON, A. George Bernard Shaw

ELLIE (levantando-se e indo em direçāo da cadeira para contemplar Mangan) Nāo é preciso que voce se preocupe tanto, Hesione. Eu tenho mais a dar a Boss Mangan do que ele tem para me dar. Eu é que estou comprando e pagando um bom preço por ele. As mulheres são melhores que os homens neste tipo de negócio. Eu avalio bem as possibilidades de Boss, e nem mesmo dez Boss Mangan me impediriam de fazer aquilo que me agradar, depois de me tornar sua mulher, o que uma moça pobre jamais poderia fazer. (Inclinando-se para a figura deitada).11

e assim, dominando o pobre homem fisicamente na cena da mesma maneira como ameaça dominá-lo espiritualmente no casamento -

Acha que me impediriam. Boss? Nāo creio. (Ela vai até a mesa e encosta-se na beirada, em frente à janela). 12

note-se que suas ações cuidadosamente preparadas são tão calmas como o tom de voz em que ela está falando -

Pelo menos não terei que passar a maior parte do meu tempo pensando quanto tempo minhas luvas irăo durar. 13

au que. Hesione, ainda sentada no sofá, agora do outro lado da sala obviamente sente a necessidade de se reafirmar, e tenta fazê-lo fisicamente além ce verbalmente:

Mrs. HUSHABYE (lvantando-se majestosamente)

o adjetivo não está aí apenas para o leitor, mas como uma orientação artistica: Hesione, a personagem, está assumindo um papel aqui -

........ (levantando-se majestosamente) Ellie, você é uma criaturinha sórdida e má. E pensar que eu concordei em conquistar essa criatura ai para salvar você dele: Muito bem, agora escute isto: se você fizer este casamento repugnante, você jamais verá Hector outra vez, não se eu puder impedir ${ }^{14}$

Mas Ellie não se altera com o desafio lançado:

Ellie (impassível) Eu fisguei Mangan dizendo-lhe que se ele não se casasse comigo jamais tornaria a ver você (ela se levanta apoiando-se nos punhos e senta-se na beira da mesa) 15 Mrs. HUSHABYE (recuando) Oh!

Lendo-se a ação descrita pode não representar nada, ou muito pouco, mas sendo representada, ela vale muito mais. Ellie está reclinada contra a ponta da mesa. suportando o próprio peso em suas mãos. Dessa posiçāo, apoiando-se em suas mãos, ela se suspende até ficar em posição sentada. Suavemente

11 SHAW, Heartbreak ..., p. 96-7.

12 Ibid., p. 97.

13 Ibld., p. 97.

14 Ibid., p. 97

15 Ibid., p. 97. 
executado o movimento parece ser descançado, mas ao mesmo tempo, parece exigir um esforço controlado, um esforço dos punhos e das mãos. Estes movimentos se ajustam perfeitamente às palavras que Ellie fala, e ao efeito da situação que Shaw armou: às palavras de Ellie são seu último golpe, o "coup de grace" ao qual Helsione somente responde com uma exclamação sem palavras e um colapso físico.

O que se pode observar aqui, é a natureza essencialmente dramática, até n'esmo teatral da imaginação de Shaw. Ele pensa em termos teatrais: seu cstilo sintetiza palavras e ações de tal forma que elas se complementam a Fonto de ambas serem expressivas. T.S. Eliot observou que um dos principais problemas enfrentados pelo poeta que tenta escrever dramas poéticos para ambientes modernos, está na dificuldade que o ator tem ao falar um verso de grande intensidade dramática enquanto responde ao telefone ou serve bebidas. Mas a questāo é que aquelas bebidas e o telefone estão lá não porque a ação requeira para determinado fim, nāo estāo lá a fim de dar a ilusāo de realidade, elas não são "ação" mas "comportamento": a palavra e o movimento não tem relacionamento direto e necessário - mas sugerem. separadamente, uma concepção de "comportamento provável" nas circunstâncias apresentadas em cena. Este é, de fato, o tipo de apresentação cênica que julgamos ser "naturalista" ou "realista", e o problema de Elliot realmente está na dificuldade de unir a atividade realista no palco com a fala irrealísta do verso - na boca dos atores. Nos dramas de Shaw, entretanto, há uma relação direta e necessária entre palavras e movimentos a ponto de quase poder se chamar seu estilo dramático, de poético, não naturalmente que a linguagem de Shaw seja poética, mas pela poesia que está na ação, ação que é, neste caso, uma unidade necessária de fala e movimento.

Da mesma forma como é um erro julgarmos Shaw como sendo um realista documentário no que se relaciona ao estilo de suas peças, creio eu ser um erro julgá-lo um realista social em qualquer sentido marxista, no que se relaciona com seus assuntos. Embora seja certo que muitos dos comentários do próprio Shaw sobre seu trabalho possam dar motivo para se pensar assim, como quando ele comenta, ao falar sobre o início de sua carreira de dramaturgo, que tendo regeitado o adultério clandestino como assunto para suas peças, ele

Tentou a ação dos senhorios de cortiços; doutrinários do amor livre; (pseudo Ibsenismo), prostituiçäo, militarismo, casamento, história, política corrente, cristianismo natural, caráter nacional e individual, parąoxos da sociedade convencional, caça ao marido, questōes de consciência, desilusōes profissionais e impostura, todos elaborados em uma série de comédias de costumes no modelo clássico. 16

16 SHAW, George Bernard. The quintessence of Ibsenism. Apud WILLIAMS, Raymond. Drama from Ibsen to Eliot. Harmondsworth. Penguin/Chatto \& Windus, 1964. p. 157. 
Raymond Williams, em seu "Drama de Ibsen a Eliot apropriadamente aprescnta como refutação a esse catálogo inocente de "bons assuntos", este comentário de Ibsen:

Tudo o que até hoje disse como poeta teve sua origem numa disposição de espírito e uma situação de vida. Nunca escrevi porque tivesse encontrado, como se costuma dizer, "um bom assunto". 17

Mas ainda que a critica de Williams tenha fundamento e seja apropriadamente exposta, não posso deixar de sentir que ele se mostra um tanto intransigente ao criticar a posiçāo de Shaw - sua posição de ousado jovem da exaltada "avant garde", e o destemido dramatizador de assuntos chocantes e até mesmo ofensivos - não posso deixar de sentir que ele está julgando apenas pelas aparências - como quando ele critica Shaw de

ao dar nome aos problemas que cada uma de suas peças aborda. ele já nos antecipa o assunto de suas peças e nos dá as explicaçōes adequadas. 18

Na realidade Shaw nos diz de que trata Pigmalion - a importância da fonética:

Mas se a peça fizer o público consciente compreender que existem pessoas que se dedicam à fonética e que essas pessoas são das mais importantes da Inglaterra, a peça terá alcançado a sua finalidade. 19

E a importância da fonética é de alcance social, até mesmo "político-social". A frase da lista de assuntos compilados por Shaw, a qual citei a pouco. e que parece ser mais apropriada a Pigmalion, seria "paradoxos de uma sociedade convencional". A ambição do Professor Higgins é transformar uma "cockney" - uma pobre vendedora de flores, numa duqueza. mudando seu comportamento, seus modos e fala, de modo que possa passar por uma verdadeira senhora da classe alta. Isto, naturalmente, ele consegue, provando assim claramente o ponto de vista de Shaw sobre a superficialidade da sociedade convencional e justificando talvez o comentário da peça feito pelo próprio autor Shaw, e exposto no seu prefácio ao discorrer sobre o notável sucesso popular que a peça alcança:

Tanto no palco como na tela, em toda a Europa e na América do Norte e na Inglaterra. Ela é tão intensa e deliberadamente didática, e seu assunto é julgado tão árido, que me agrada sobremaneira atirar na cara dos sabichöes entendidos, que repetem como papagaios que a arte jamais deveria ser didática. A peça está aí para provar a minha afirmaçāo de que a verdadeira arte nāo pode jamais ser outra coisa. 20

17 WILLTAMS, p. 158.

18 Ibid., p. 157 .

19 SFAW, George Bernard. Pygmalion. London, Longman, 1971. p. 4.

20 Tbid., p. 4-5. 
Os sabichões entendidos, poderāo entretanto replicar que o sucesso de Pigmalion se deve não tanto ao seu assunto árido como ao séu humor e estilo elegante. Mas aqui temos no ato $\mathrm{V}$ uma das melhores passagens ca peça que confirma essas qualidades onde Eliza diz ao Coronel Pickerin porque ela deve muito mais a ele do que a Higgins, que, com sua mãe está presente durante a cena:

LIZA (sem prestar atenção a Higgins) - Agora que o experimento terminou, Coronel Pickering, o sr. vai me descartar?

CORONEL PICKERING - Oh, não diga isso. Você não deve pensar em tudo isso como um simples experimento. Isso me choca, não sei bem como.

LIZA - Não é porque o sr. tenha pago meus vestidos. Eu sei que o sr. é generoso com todo o mundo em matéria de dinheiro. Mas foi do sr. que eu aprendi boas maneiras, e - é isso que faz da gente uma dama, não é? Veja o sr. - isso era muito dificil para mim, com o exemplo do Prof. Higgins sempre em minha frente. Eu fui criada para ser exatamente como ele - incapaz de me controlar, e a usar palavrōes à menor provocação. Eu jamais saberia que senhoras e cavalheiros nāo se portam assim se o sr. não tivesse estado lá.

HIGGINS - Muito bem!

PICKERIN - Oh. é apenas o geito dele. Ele nāo faz por mal. LIZA - Eu também não fazia por mal quando cra uma simples vendedora de flores. Era apenas o meu geito. Mas mesmo assim eu fazia isso, e isso é que faz a diferença afinal.

PICKERIN - Não há dúvida. Contudo ele ensinou voce a falar, e eu não poderia ter feito isso, voce sabe.

LIZA - displiscentemente. Naturalmente. Essa é a profissāo dele. HIGGINS - Maldição!

LIZA (continuando) - Foi apenas como aprender a dançar de acordo com a moda, nada mais do que isso. Mas o sr. sabe o que foi que começou realmente a me educar?

PICKERIN - 0 que?

LIZA (parando seu bordado por um momento) - Quando o sr. me tratou de Srta. Doolittle. Naqucle dia quando cheguci a Wimpole Street. Aquele foi o momento em que senti, pela primeira vez um sentimento de respeito próprio. (Ela continua seu trabalho). $\mathrm{E}$ havia centenas de coisas que o sr. nunca notava, porque clas ocorriam naturalmente no senhor. Coisas como levantar-se, tirar o chapéu, abrir portas.

PICKERIN - Oh, aquilo não era nada.

LIZA - Sim, eram coisas que mostravam que o sr. pensava e sentia em relação a mim como sendo algo melhor que uma simples lavadora de pratos, embora eu saiba que o sr. trataria da mesma maneira uma lavadora de pratos se ela se encontrasse numa sala de visitas. O sr. nunca tirou as botas na sala de jantar quando eu estava lá.

PICKERIN - Vocĉ não deve ligar para essas coisas. Higgins tira suas botas em qualquer lugar.

LIZA - Eu sei. Eu não o culpo. E o seu geito, não é? Mas para mim fazia muita diferença que o sr. não fizesse isso. 
O espírito, a elegância.e. .o humor não sāo uma camada assucarada, destacável de uma pilula didática: eles surgem da própria natureza da mensagem da moral que está sendo transmitida. Humor e moral năo sāo coisas opostas, separadas - são uma coisa só, além disso, o humor é em si mesmo uma parte integrante da mensagem. Ele opera como modificador da mensagem. Higgins crê que ao mudar o comportamento de Eliza, ele mudou tamlém a maneira em que as pessoas a tratam:

Você logo verá se ela tem alguma idéia que eu não tenha posto em sua cabeça ou alguma palavra que eu não tenha posto em sua boca. Eu afirmo - eu criei essa criatura do que era antes um produto saido do monte de lixo de Coven Garden. E agora ela vem fingir de grandè dama comigo. 22

Mas o diálogo na cena que segue este desabafo, a cena de que estamos tratando, deixa bem claro que, em grande parte, seu comportamento mudou devido à mancira pela qual ela fora tratada nas diversas situações em que cla se encontrou. Pickerin tratou-a como se ela fosse uma senhora, e ela foi estimulada a corresponder a seu tratamento bondoso e gentil. E não \& este um ponto inesperado ou novo, uma revelação de último ato de Shaw: através de toda a peça revelou a verdade implicita daquilo que Eliza agora explicitamente confirma. A cena gloriosamente comica, no laboratório de Higgins, em Wimpole Street, onde ela chega pela primeira vez para pedir-lhe liçōes, já apresenta esse fato:

Higgins (perentoriamente) - Sente-se.

A vendedora de flores - Oh! se o sr. é tão gentil...

Higgins (gritando) - SENTE-SE.

A sra. Pearse (severamente) - Sente-se menina.

Faça o que lhe mandam.

A vendedora de flores - Oh! (Ela levanta-se, meio revoltada, meio assustada).

Pickerin (muito amável) - Quer fazer o favor de sentar-se?

(Ele coloca a cadeira perto do tapete da estufa entre ele e Higgins).

Liza (timidamente) - Prá mim tanto faz. Bem, posso sentar-me.

(Ela senta-se. Pickerin volta para perto da estufa). 23

Maus tratos provocam revolta e má vontade; bondade e gentileza produzem resultados positivos. $O$ enredo da peça plenamente reforça esta asserçāo, naturalmente, fazendo com que Eliza se empenhe para assegurar e estender estes resultados, não por temor ou por desejo de tirar vantagens para si, mas por afeiçāo por Pickerin e Higgins, até mesmo seu amor por Higgins.

Sr. Higgins - Acredito que sei muito bem o que você fez. A moça é de natureza bastante afetiva, não é sr. Doolittle?

Doolittle - Tem um coração muito sensível. Puxou por mim.

Sr. Higgins - Exatamente. Ela se afeiçoou a voces dois. Ele se esforçou por você. Henry. Não sei se você percebe o que esse esforço

22 SHAW, Pygmalion, p. 82

23 Ibid., p. 24. 
mental significa para uma moça dessa classe. Bem, parece que quando o grande dia da prova chegou, e ela fez essa coisa maravilhosa para você, sem fazer nem sequer um pequeno engano, vocês dois sentaram-se na sala e se congratularam mútuamente por tudo ter saído tāo bem e fclizes por terem terminado todos os aborrecimentos $e$ cansaço, e nem sequer falaram com Eliza. E você se surpreende porque ela atirou os chinelos em você. Eu. em seu lugar, teria atirado as ferragens da lareira. 24

Se devemos extrair uma alegoria de nível sócio-político da fábula de Pygmalion, - e parece mesmo que Shaw nos oferece amplos indícios para fazermos algo desse gênero, então ficará evidenciado claramente o que George Orwell, ao interpretar as injustiças sociais apresentadas por Dickns, chamou de "a grande panacea Victoriana da mudança de sentimentos". E o amor que redime a sociedade e que erradica as injustiças sociais, e nāo é a mudança de leis ou redistribuiçāo de riquezas. Essas medidas apenas aliviam os sintomas, mas sem curar a doença. Uma das mais irônicas demonstraçōes disto em Pygmalion está no contraste entre os destinos de Eliza e de seu pai. Eliza é amada por mais estranhas que sejam as demonstrações de Higgins a esse rcspcito - ela é amada, tratada com afcição, nutrida e educada, e o resultado é que ela se transforma numa pessoa melhör. e de personalidade mais forte do que era antes. Doolittle, por outro lada: recebe $\mathbf{4 . 0 0 0}$ libras ao ano, com o único resultado que ele e a mulher que ele ama se curvam à moralidade de classe média, perdendo assim todo o vigọr e pujança de seu espírito. $O$ que realmente muda as pessoas nāo é o scu comportamento, a maneira em que elas podem se comportar, seja pelo dinheiro ou por boas maneiras a mesa, mas sim, o modo como são tratadas, como sāo compreendidas, como são ligadas aqueles que os cercam.

Eliza Veja você, na realidade, deixando de lado as coisas que qualquer um pode conseguir (a roupa, a maneira de apresentar-se e a maneira apropriada de falar, etc.) a diferença entre uma senhora e uma pobre vendedora de flores, nāo está em como ela se comporta mas na maneira como é tratada. Eu sempre serei apenas uma vendedora de flores para o Professor Higgins porque ele sempre me tratará assim. Mas eu sei que posso ser uma verdadeira senhora para o sr. Coronel Pickerin, porque o sr. sempre me tratou como sc eu fosse uma senhora e sempre me tratará assim. 25

A questāo é social e até mesmo política, mas não é como afirmei ao começar esta digressāo sobre Pygmalion. nāo é feita de uma maneira totalmente social-realista: a peça é uma fábula, como seu título esclarece ao chamar a atençāo para o arquetipo mítico. E uma fantasia. um símbolo metáfora, alegoria, qualquer que seja o termo que vocês queiram usar para descrevê-la, o ponto essencial é que a preocupação de Shaw é menos com o mecanismo mundano da sociedade, da política, das finanças, do que com os fatores morais implicados nessas coisas, estes afetam, até mesmo criam,

24 SHAW, Pygmalion, p. 89-90.

25 Ibld., p. 93-4. 
este "mecanismo mundano". Por conseguinte suas formas dramáticas e seus assuntos dramáticos não são observaçōes naturalistas do mecanismo, mas cstratagemas parabolicamente intrincados para ignorar o mecanismo, os fatos acidentais da vida externa, para escapar da necessidade de seguir o que c próprio Shaw chamou de "a ordem casual dos acontecimentos na vida ! eal", e concentrar-se nos valores básicos morais, na qualidade essencialmente moral de seus temas.

Isto se aplica não somente à peças como Pygmalion - parábola aberta - elegante e espirituosa, mas a peças como Major Barbara de cujo prefácio. já foi citada a frase sobre "a ordem casual dos acontecimentos na vida real" como vocês devem lembrar, peça essa bem mais seria e intensa mas nem por isso feito de maneira menos elegante, ou aparentemente mais diretamente política.

BARBARA. Matar. E essa sua solução para tudo? UNDERSHAFT. E o teste final que convence, a única alavanca suficientemente forte para mudar o sistema social. A única forma convincente. Deixem à solta pelas ruas seiscentos e setenta idiotas e três policiais poderão dispersá-los. Mas ponha-os juntos em certa casa em Westminster e deixe-os praticar certo cerimonial e darem a si mesmos certos nomes até que cles se sintam com coragem de matar; e os 670 idiotas se transformam em governo. A massa crédula preenche as cédulas para votar e imagina que governa seus senhores; mas a cédula que realmente governa é aquela que está embrulhada numa bala de revólver. 25

Argumentos poderosos. Mas certamente o que Shaw está defendendo é uma violenta revolução no coraçāo e na alma dos homens. e a retorica de Undershaft, da mesma maneira que a sua profissão de fabricante de armas, ¿ para Shaw uma metáfora exposta de maneira poderosamente dramatica para fins essencialmente internos. Mesmo no prefácio onde ele nos fala por si mesmo e em termos menos palpáveis, mais abstratos. menos dramáticos, Shaw continuamente gira ao redor de análises economicas para citação de provérbios de redençāo apocaliptica.

Ele começa um parágrafo assim:

"a ponto de que o exército não deve aceitar esse dinheiro".

refere-se ao Exército de Salvação e ao dinheiro dos fabricantes de armas e dc destiladores de whisky.

A sua justificação é óbvia. O Exército de Salvação deve aceitar o dinheiro porque ele não pode existir sem dinheiro. e não há outro modo de consegui-lo. Praticamente todo o dinheiro disponível do país consiste num montante de rendas, juros ou lucros do qual cada centavo está ligado ao crime, à bebida, à prostituição, a doenças e a todos os maléficos frutos da pobreza, tăo intimamente ligado quanto está a empresas, riquezas, probidade comercial e prosperidade nacional. A idéia de que você possa marcar certas moedas com o estigma de corrupção é uma superstição individualista e impraticável.

26 SHAW, Major ..., p. 143-4. 
Ele está enfatizando o lado prático, mas a medida que sua argumentação avança, sua pressão apocaliptica se torna mais e mais evidente, até alcançar o climax nesta passagem:

... um jovem entusiasta clérigo da Igreja Estabelecida, não se beneficia por recusar-se a receber dinheiro de qualquer fonte e só aceitá-lo quando provem de senhoras respeitáveis com rendimentos independentes e recomndáveis modos de vida. Basta que ele investigue até a fonte industrial da renda dessas gentis senhoras e lá ele encontrará a profissāo da senhora Warren (prostituiçāo) a carne estragada enlatada. (toda uma série de coisas semelhantes). Os seus próprios proventos tem a mesma origem. Ele primeiro precisa salvar a honorabilidade do mundo se quizer salvar a dele próprio 27

E aqui se ouve menos a voz do socialista Fabiano que a do idealista Shelleyano, anunciando uma revolução mais cultural que social e "Major Barbara", no seu visionário extasis final, é o arauto de uma profecia que se aproxima mais ao entrelaçamento do Céu e da Terra de Blake do que a um manifesto comunista.

CUSINS. Pensei que você tivesse resolvido virar as costas ao lado mau da vida.

BARBARA. Não há lado mau. A vida é uma só. Eu nunca quis me omitir ou negar a minha contribuição a qualquer mal que deve ser suportado, seja ele pecado ou sofrimento. 28

E ainda:

CUSINS. Então o caminho da vida está situado através a fábrica da morte?

BARBARA. Sim, através da elevaçāo do inferno para o céu, do homem para Deus, através da revelaçāo de uma luz eterna no vale dos sonhos. 29

A revoluçāo exigida é essencialmente metafísica: um refazer de valores convencionais, e transcende o bem e o mal no sentido dado a essas palavras pela sociedade constituida.

CUSINS. Vocè chama a pobreza de crime?

UNDERSHAFT. O pior dos crimes. Todos os outros crimes são virtudes comparados a ela; todas as outras desonras são virtudes cavalherescas em comparaçāo a ela. A pobreza arruina cidades, espalha horriveis pestilencias, fere mortalmente a própria alma dos que se aproximam ao alcance de sua vida, som ou cheiro. $O$ que você chama de crime não é nada - um assassinato aquii, um roubo lá, um golpe, uma praga de vez em quando, que importa isso?; São apenas acidentes e males da vida; não há 50 criminosos genuinamente profissionais em Londres, mas há milhōes de gente pobre, gente suja, mal alimentada, mal vestida. Eles nos envenenam moral e

27 SHAW, Major ..., p. 26-7.

28 Ibid., p. 151.

29 Ibid., p. 152. 
fisicamente; eles matam a felicidade da sociedade, eles nos forçam a nos livrarmos de nossas proprias liberdades e a organizar crueldades desnaturadas. com medo que eles se levantem contra nós e nos arrastem para o abismo. Somente os tolos temem o crime, mas todos tememos a pobreza. 30

A única resposta possivel é uma espécie de "desejo de poder" nieitscheneano, uma força de querer avassaladora, uma resolução espiritual que capacite o individuo a operar uma mudança radical em si mesmo; e assim. em seu relacionamento com os outros e, por conseguinte, eventualmente, na sociedade, e a fazer isso de uma maneira totalmente corajosa e, na palavra que Andrew Undershaft se orgulha de ter escrito nas paredes de sua fábrica, cespudoradamente. Shaw leu Nietzsche - ele o cita no epilogo de Pygmalion, e muita coisa em Zarathustra poderia quase que totalmente ser incorporado no diálogo de "Major Barbara":

Na verdade eu afirmo: $O$ bem e o mal imutável não existem. Eles tem que lutar continuamente contra influênciais externas. Você exerce poder com seus valores e doutrinas sobre o bem e o mal, sua escala de valores - e estes são baseados em seus gostos. scus receios e hesitaçōes escondidos em sua alma. mas forças mais poderosas e dominadoras surgem de fora desses valores: o ovo e a sua casca quebram-se contra ela: E aquele que deseje crer o bem e o mal, verdadeiramente terá primeiro que destruir seus valores. Assim o maior dos males se funde no maior dos bens - este é contudo, o bem criador. 31

Assim falou Zarathustra. E assim também fala Andrew Undershaft:

Eu era um "East Eantesh", eu pregava moral e passava fome até que um dia eu jurei que seria um homem livre e bem alimentado a todo custo, que nada me impediria de conseguir isso a não ser uma bala; nem a razāo nem a moral nem as vidas de outros homens. Eu disse: você passará forme antes que eu passe fome; e com estas palavras eu me tornei livre e grande. Eu era um homem perigoso até que consegui o que queria. Agora eu sou pessoa util, benfeitora, bondosa. Prefiro ser um ladrāo a ser escravo. Não quero ser nem um nem outro, mas se tiver que escolher, então, por Deus, eu escolherei a opção mais corajosa e mais moral. Odeio a pobreza e a escravidão mais do que qualquer outro crime. 32

E esta força de vontade, esta percepçāo e este propósito não amoral mas supermoral, que Shaw dramaticamente concretiza na peça, nos canhões, bombas e metralhadoras da fábrica da morte.

BARBARA. Não há poder mais forte que aquele? (apontado para as bombas).

CUSINS. Sim mas aquele poder é capaz de destruir os poderes mais elevados da mesma maneira que um tigre pode destruir um homem: portanto o homem deve primeiro dominar aquele poder. 33

30 SHAW, Major ..., p. 142.

31 Ibid., p. 139.

32 Ibid., p. 143.

33 Ibid., p. 150 . 
Porque, como Cusins já chegou a compreender.

Você nāo pode ter o poder de fazer o bem sem ter também poder para fazer o mal. Este poder que destrói os homens fazendo-os em pedaços, jamais foi tão terrivelmente usado como o poder intelectual, o poder imaginativo, o poder poético e o poder religioso. que podem escravizar as almas dos homens. Como professor de Grego eu tenho as armas do homem intelectual contra o homem comum. Eu quero um poder que seja suficientemente simples para ser usado pelo homem comum, mas que seja entretanto bastante forte para forçar a oligarquia intelectual a usar seu genio para o bem geral. 34

Quando Barbara e Cusins se casam, e eventualmente passam a dirigir a firma de armamentos de Undershaft e Lazarus, há uma fusão metáforica de uma exaltação espiritual e profundidade intelectual que se tornam as forças orientadoras e inspiradoras a agir por traz do poder prático e material das máquinas. As armas são em si mesmas neutras e inúteis: "Eu posso fabricar canhões, diz Undershaft, numa passagem do último ato, não posso fabricar coragem e convicções" Barbara e Cusins sāo os que podem fazer isso.

Mas essa posiçāo é perigosa: a intoxicação espiritual é uma arma de dois Eumes, e se passarmos de "Major Barbara" apresentada pela primeira vez em 1905, e publicada em 1907, para "Heartbreak House", publicada em 1919, é como penetrar num mundo totalmente diferente, como aliás o próprio título da última peça sugere. Ao passo que "Major Barbara" termina em extase e conversão, no antever de uma luz eterna, Heartbreak House termina em escuridão e desilusão. $O$ que aconteceu para motivar esta mudança de atitude foi, naturalmente como podemos ver pela data, a grande guerra. $O$ apocalipse do fim da primeira peça sugeria essa promessa de redençāo, realmente rebenta na Europa, mas ela traz consigo não a Nova Jerusalém. mas Armaggedon. Em Major Barbara, Shaw põe na boca de Undershaft que parce ser mais que qualquer outro personagem, o seu porta-voz:

Esta sociedade não pode ser salva até que os professores de grego se dediquem a fabricar polvora, ou entāo os fabricantes de polvora se tornem professores de grego .35

De onde se deduz que no final da peça o Professor de Grego faz exatamente o que parecia ser óbvio. Mas quando Shaw escreve o prefácio de Heartbreak House ele lembra-se daquelas esperanças que acalentava, com bem menos otimismo.

34 SHAW, Major ..., p. 150.

35 Ibid., p. 147. 
A guerra nāo mudou a mentalidade das pessoas de maneira que parecesse impossivel. O que realmente aconteceu foi que o impacto da morte e destruição físicas - a única realidade que qualquer tolo pode realmente entender, arrancou a máscara de educaçāo, arte, ciência e religião que encobria a nossa ignorância e barbarismo e nos deixou grotescamente orgulhosos da liberdade repentinamente concedida às nossas mais vis paixōes e mais despreziveis temores. Desde que Thucidedes escreveu sua história tem-se repetido que quando o anjo da morte faz soar suas trombetas são arrancadas as mascaras da civilizaçāo das cabeças dos homens e atiradas na lama, como chapeus num golpe de vento. Mas quando essa profecia se realizou entre nós, o impacto causado não foi atenuado pelo fato de que alguns estudiosos de história grega nāo fossem surpreendidos por ela. Na verdade esses mesmos estudiosos se atiraram tāo despudoradamente na orgia como os iletrados. Os sacerdotes cristãos juntaram-se à dança da guerra sem mesmo arrancar suas batinas primeiro, e o respeitável diretor da escola ao expulsar com insultos o professor de alemäo e ao declarar que nenhuma criança inglesa jamais deveria aprender novamente a linguagem de Goethe, ambos apoiados pelo repúdio mais impudente daqueles que representam toda a decência da civilização e toda a lição de experiência política por parte das próprias pessoas que, como professores universitários. historiadores, filósofos e homens de ciência, eram os guardiāes reconhecidos da cultura. 36

Shaw nāo oferece in Heartbreak House um repúdio ao idealismo tāo cxaltado e exaltante como é expresso em "Major Barbara", mas nesta peça cxibe realmente um ceticismo maior e mais radical sobre a possibilidade da réalização prática neste mundo, desse idealismo. As consideraçōes que se acham em "Major Barbara", também estāo presentes neste diálogo do primeiro ato de Heartbreak House, mas elas agora sāo expressas com um toque de desesperança, de desengano, de quieto, comedido, mas profundo desespero:

Capitão Shotover. E que devemos fazer? Devemos ficar para sempre enterrados na lama por causa desses porcos para quem o universo nāo passa de uma máquina para engraxar seus pelos e seus focinhos?

Hector. São os pelos dos Mangans piores que os cachos dos Randalls?

Cap. Shotover. Devemos conseguir poderes de vida e morte sobre ambos. Eu me recuso a morrer até que tenha inventado os meios. Hector. Quem somos nós para julgá-los?

Cap. Shotover. Quem são eles para julgar-nos?

No entanto eles nos julgam, sem hesitar. Há inimizade entre nossa classe e a deles. Eles sabem disto e agem baseados nisto, sufocando nossas almas. Eles acreditam neles mesmos. Quando nós acreditarmos em nós mesmos nós os venceremos.

Hector. E a mesma classe. Você esquece que seu pirata tem uma filha muito bonita. O filho de Mangan pode vir a ser um Platāo, e o de Randall, um Shelley. O que foi meu pai?

Cap. Shotover. O pior malandro que já encontrei. (Ele cobre a plan-

36 SHAW, Heartbreak ..., p. 14-5. 
cheta e senta-se e começa a misturar as tintas).

Hector. Precisamente. Bem, você se atreveria a matar seus inocentes netos?

Cap. Shotover. Eles são meus netos também.

Hector. Exatamente. Somos todos membros da mesma família. (jogando-se descuidadamente no sofá) Eu lhe confesso que sempre pensei no exterminio desses parasitas humanos. Muitos homens já pensaram nisso. Os homens decentes são como Daniel na cova dos leōes, a sua sobrevivência é um milagre, e eles nem sempre sobrevivem. Vivemos entre os Mangans e os Randalls e Billys Dun, assim como eles, pobres diabos, vivem entre germens mortais e os médicos, advogados e os padres e os maitres de restaurantes e comerciantes e serventes e todo o resto de parastias e chantagistas. Que são nossos terrores comparados com os deles? Dê-me o poder de matá-los e eu os pouparia na mais pura...

Cap. Shotover (interrompendo-o ásperamente) Por sentimento de fraternidade?

Hector. Nāo. Eu me suicidaria se acreditasse nisso. Eu preciso acreditar que minha centelha, embora pequena - é divina, e que a luz vermelha sobre suas portas - é fogo do inferno. Eu os pouparia por pura magnânima piedade.

Cap. Shotover. Você näo os pode poupar até que você tenha o poder de matá-los. No momento, ele é que tem o poder de matar você. Há milhōes de negros prontos para serem treinados e soltos sobre nós. Eles vão fazer isso. Eles já estāo fazendo isso.

Hector. Eles são estúpidos demais para usar seu poder.

Cap. Shotover. (deixando o pincel e indo para o sofá). Não se iluda. Eles realmente o usam. Nós matamos a melhor metade de nós mesmos todos os dias, para propiciá-los. O conhecimento de que essa gente está lá para tornar inútil todas as nossas aspiraçōes nos impede de ter aspiraçōes. E quando somos tentados a procurar destruí-los eles produzem demonios para enganar-nos, disfarçados em belas moças, cantores e poetas e similares, por cuja causa nós os poupamos.

Hector. (sentando-se inclinando-se para ele) Nāo será Hecione um desses demonios criados por você para evitar que eu o apunhale? Cap. Shotover. E possivel. Ela usou você e nāo lhe deixou nada a não ser sonhos - como fazem algumas mulheres.

Hector. Mulheres vampiros. Mulheres demonios.

Cap. Shotover. Os homens pensam que vale a pena perder o mundo por causa delas, e o perdem de boa vontade. Quais sāo os homens que realizam alguma coisa? Os maridos das megeras, das bébadas, os homens com os espinhos na carne. 37

De fato, talvez seja típico da genialidade de Shaw que esta peça seja ao mesmo tempo, a mais engraçada e a mais sombria de suas peças e que mais se move em forma de pesadelo. Ela está crivada de dúvidas e incertezas. Hector Hushabye é evidentemente uma pessoa da elite, o par perfeito de Adolphus Cusins na "oligarquia intelectual", ambos corajosos e elegantes, mas a única aplicação prática de seus talentos consiste em dizer mentiras às mulheres, ainda que, como é típico em Shaw, essas estórias que Hector conta possam ou näo ser mentiras.

37 SHAW, Heartbreak ..., p. 76-7. 
Sra. HUSHABYE. Ele nunca se vangloria de coisas que ele tenha realmente feito. Não suporta isso e fica realmente acanhado se alguém menciona essas coisas. Todas suas estórias sāo inventadas.

ELLIE (aproximando-se dela) Você quer dizer que ele é realmente corajoso e que ele tem eventuras reais e apezar disso inventa coisas que ele jamais fez e que jamais aconteceram?

Sra. HUSHABYE. Sim, minha menina, Isso mesmo. As pessoas năo possuem vícios e virtudes classificados em grupos. Elas as possuem mesmo assim - todas misturadas. 38

Há na moral de Hacione um pouco de realismo psicológico tolerante que pode mesmo ser um truismo se nāo invulgaridade, mas de uma espécie que justifica sua repetição, especialmente com tal clareza e precisão. Mas o fato de que essa moral seja apresentada através de uma passagem de uma comicidade selvagem e fantástica. de importância funcional muito mais exfressiva para o enredo da peça que a própria moral, não é simplesmente lim paradoxo Shawiano. Num mundo sombrio, sem ilusōes, mesmo cínico como o de Heartbreak House, os limites entre a verdade e o que um mundo convenciona chamar de objetividade e aparências, de máscaras, esse mundo caracteriza como falsos os limites que são sempre dificeis de definir no drama de Shaw, esses limites são em Heartbreak House, totalmente removidos, é a realização máxima de todas as peças de Shaw, do subjetivismo profundo que é a essencia da tradição romântica, e a qual ele tão claramente pertence. "O que é a Verdade?, diz ele, repetindo Pilatos, e não espera por uma resposta. Se ele esperasse, que resposta obteria? Não há a menor dúvida: Jesus teria dito "Eu sou a Verdade". Esta é também a resposta de Shaw à pergunta "O que é a Verdade?". Porque afinal, neste nivel radical de consciência em que ele está interessado, o que é verdade, qual é a Verdade? talvez seja a descoberta de que nenhuma verdade pode ser desvendada a näo ser a verdade que você realmente é; e que não há verdade ou sentido ou significado a não ser a verdade que você mesmo lhe dá; que a verdade é um conceito que pertence à mente humana e que fora da mente e da vontade bumana não existe essa coisa absoluta -a verdade. Neste plano, a verdade ç̊ é algo que pode ser provado ou desmentido, ela é algo que você cria.

ELLIE, moral: não beba cachaça.

CAPITAIN SHOTOVER. (vehementemente) E uma mentira menina. Deixe um homem beber 10 barris de rum por dia e cle nāo será um bébado. Enquanto ele puder seguir seu rumo permanecer no seu barco e guiá-lo ele não será um bêbado. 0 homem que fica bebendo em sua cabine e confia na Providência - esse eu chamo de marujo bêbado, ainda que ele não bebesse nada mais que água do rio Jordāo. ${ }^{39}$

Mas afirmar tudo isso não é certamente separar o drama de Shaw da sociedade e da política, apenas para salientar que, para Shaw as considera-

38 SHAW, Heartbreak ..., p. 62-3.

39 Ibid., p. 140-1. 
çōes políticas năo são considerações sobre o que é prático e vantajoso, mas sim sobre o que é criativo, sobre o que dignifica a vida. No auge do entusiasmo em um raide aéreo, no final da peça Heartbreak House, o Capitão Shotover diz umas palavras que exprimem resumidamente a profecia anunciada pela arte de Shaw:

O julgamento chegou. A Coragem nāo vos salvará mas mostrará que vossas almas ainda estão vivas. 40

\section{REFERENCIAS BIBLIOGRAFICAS}

SHAW, George Bernard. Heartbreak house. London, Longmans, 1961. $197 \mathrm{p}$. Ma.jor Barbara. Harmondsworth. Penguin, 1974. $152 \mathrm{p}$.

Major critical essays. London, Contable, 1955. 331 p.

Pygmalion. London, Longman, 1971. $150 \mathrm{p}$.

WILLIAMS Raymond. Drama from Ibsen to Eliot. Harmondsworth Penguin/Chatto \& Windus, 1964. $314 \mathrm{p}$.

\section{Resumo}

O autor afirma que Shaw, em qualquer avaliação da literatura británica, clurante o século passado e o começo deste, merece um lugar proeminente. lima das razōcs para isso, ¿́ que Shaw foi um escritor que percebeu a necessiciade premente das mudanças sociais e tentou tornar essa necessidade evidente aos olhos dos outros.

Desenvolvendo esse tema, o autor trata da centralidade das questōes levantadas nas peças de Shaw, em relação aos problemas sociais, políticos, culturais e morais da época. No desenvolvimento cênico daquelas questōes, Shaw desenvolve uma técnica teatral rigorosa e minuciosa em que os menores detalhes, formando um conjunto de expressão, são previamente controlados pelo dramaturgo, em suas instruções cênicas, onde o elemento visual do esquema da peça é tão importante como o elemento verbal, e os gestos dos atores sāo cuidadosamentc cronometrados, de modo que. lendo-se uma ação descrita, ela pode representar quase nada, mas sendo encenada, ela adquire um alto valor de comunicação.

\section{Summary}

The author says that there are a number of very good reasons why Bernard Shaw deserves a prominent place in any survey of British literature during the last century and one of them is that Shaw was a writer who saw the pressing necessity for social change, and tried, through his art, to make that necessity apparent to others.

40 SHAW, Heartbreak ..., p. 143. 
TOMLINSON, A. George Bernard Shaw

Developing this theme, the writer treats of the centrality of the issues raised in Shaw's plays, to social, political, cultural and moral concerns of the age.

Shaw makes a powerful use of action and setting and he is very detailed and precise about both of them in his stage directions where the visual element of the design of his plays is as important as the verbal element and the gestures of the actors are very precisely tuned so that in reading the action given, these could go for nothing but in performance it counts for much more. and it attains a high power of communication. 